\title{
Physico-chemical thresholds in the distribution of fish species among French lakes
}

\author{
Vincent Roubeix $^{1, *}$, Martin Daufresne ${ }^{1}$, Christine Argillier $^{1}$, Julien Dublon ${ }^{1}$, Anthony Maire ${ }^{1, a}$, \\ Delphine Nicolas ${ }^{1, \mathrm{~b}}$, Jean-Claude Raymond ${ }^{2,3}$ and Pierre-Alain Danis ${ }^{2}$ \\ ${ }^{1}$ Irstea, UR RECOVER, Pôle AFB-Irstea hydroécologie plans d'eau, Centre d'Aix-en-Provence, 3275 route Cézanne, \\ 13182 Aix-en-Provence, France \\ ${ }^{2}$ Agence française pour la biodiversité, Pôle AFB-Irstea hydroécologie plans d'eau, 13182 Aix-en-Provence, France \\ 3 Agence française pour la biodiversité, Délégation Régionale Rhône-Alpes, Unité Spécialisée Milieux Lacustres, \\ 74200 Thonon-les-Bains, France
}

\begin{abstract}
The management of lakes requires the definition of physico-chemical thresholds to be used for ecosystem preservation or restoration. According to the European Water Framework Directive, the limits between physico-chemical quality classes must be set consistently with biological quality elements. One way to do this consists in analyzing the response of aquatic communities to environmental gradients across monitoring sites and in identifying ecological community thresholds, i.e. zones in the gradients where the species turnover is the highest. In this study, fish data from 196 lakes in France were considered to derive ecological thresholds using the multivariate method of gradient forest. The analysis was performed on 25 species and 36 environmental parameters. The results revealed the highest importance of maximal water temperature in the distribution of fish species. Other important parameters included geographical factors, dissolved organic carbon concentration and water transparency, while nutrients appeared to have low influence. In spite of the diversity of species responses to the gradients, community thresholds were detected in the gradients of the most important physico-chemical parameters and of total phosphorus and nitrate concentrations as well. The thresholds identified in such macroecological study may highlight new patterns of species natural distribution and improve niche characterization. Moreover, when factors that may be influenced by human activities are involved, the thresholds could be used to set environmental standards for lake preservation.
\end{abstract}

Keywords: ecological threshold / gradient forest / fish / lake / water quality

Résumé - Seuils physico-chimiques dans la distribution des poissons des plans d'eau français. La gestion des plans d'eau nécessite la définition de seuils physico-chimiques pour la préservation ou la restauration des écosystèmes. Selon la Directive Cadre européenne sur l'Eau, les limites de classes de qualité physico-chimiques doivent être fixées en cohérence avec les éléments de qualité biologique. Une façon de faire consiste à analyser les réponses des communautés aquatiques aux gradients environnementaux formés par les sites de monitoring et d'identifier des seuils écologiques de communautés, c'est-à-dire des zones dans les gradients où le turnover des espèces est le plus important. Dans cette étude, les données de pêches provenant de 196 plans d'eau ont été considérées pour rechercher des seuils écologiques avec la méthode de gradient forest. L'analyse a porté sur 25 espèces avec 36 paramètres environnementaux. Les résultats ont révélé que la température maximale était le facteur le plus important dans la distribution des espèces de poissons. Les autres paramètres importants étaient les facteurs géographiques, la concentration en carbone organique dissous et la transparence de l'eau alors que les nutriments semblaient avoir peu d'influence. Malgré la diversité de réponses des espèces aux gradients, des seuils de communautés ont été détectés dans les gradients des paramètres physico-chimiques les plus importants ainsi que dans ceux des concentrations en phosphore total et en nitrates. Les seuils identifiés dans une telle étude macroécologique peuvent faire apparaître de nouveaux patrons de

\footnotetext{
${ }^{a}$ Present address: EDF R\&D, LNHE (Laboratoire National d'Hydraulique et Environnement), 6 quai Watier, 78401 Chatou, France.

${ }^{\mathrm{b}}$ Present address: Research Institute of Tour du Valat, 13200 Arles, France.

*Corresponding author: vincent.roubeix@irstea.fr
} 
distribution naturelle des poissons et améliorer la caractérisation des niches spécifiques. De plus, quand des facteurs influencés par les activités humaines sont impliqués, ces seuils pourraient être utilisés pour fixer des limites pour la protection des plans d'eau.

Mots-clés : seuil écologique / gradient forestier / poisson / lac / qualité de l'eau

\section{Introduction}

Water quality of natural aquatic systems was primarily assessed in history by chemical methods. The first environmental standards for lakes were only based on physicochemical parameters such as phosphorus concentration or water transparency (Vollenweider, 1975; OECD, 1982). Although they could best account for the effects of pollution, biological indicators were neglected because they were less quantitative and their interpretation for management was complex (James, 1979). Today, the necessity of biological assessment is well recognized and a high importance is given to bioindicators in the evaluation of surface waters. In Europe, a change in water management from chemical towards ecological targets has been implemented by the European Water Framework Directive (WFD, European Commission, 2000). In this context, water physico-chemical parameters are considered as a support of biological quality elements, i.e. phytoplankton, phytobenthos, macrophytes, macroinvertebrates and fish.

Six physico-chemical quality elements are identified by the WFD for lakes: transparency, temperature, oxygenation, salinity, pH and nutrients (EEB, 2001). For each of them, boundaries must be set between five classes of ecological status. Purely statistical methods based on percentile analysis, gradient division or expert judgment are most often used to determine the limits of quality classes (Chambers et al., 2012). However, as the physico-chemical elements support the development of aquatic communities, ecological boundaries should be set from the analysis of biological responses to changes in water quality (Birk et al., 2012).

Ecosystems may respond linearly to a gradual change of an environmental variable but mathematical models (May, 1977) and empirical observations (Scheffer and Carpenter, 2003) suggest that the response may be rather discontinuous with sharp transitions between multiple stable states. The theory of ecological thresholds provides an interesting framework to derive ecologically relevant class boundaries (Groffman et al., 2006). An ecological threshold is a zone in a gradient where small changes in a control variable produce large responses of an ecosystem. Ecological thresholds can be detected from time-series in a single site or from the analysis of environmental gradients across many sites (Andersen et al., 2009). Although the approach in time is more intuitive to address the question of thresholds, the recent development of great observational networks in the context of the WFD offers the opportunity to analyze gradients in the large databases generated, operating in this way a time-for-space substitution (Fukami and Wardle, 2005; Mac Nally et al., 2014). Thresholds appear as a breakpoint in the non-linear relationship between a biological descriptor and an environmental factor. Most examples found in the field of aquatic ecology concern the response of macroinvertebrates, macrophytes or microalgae to one anthropogenic pressure in streams (Richardson et al., 2007; Evans-White et al., 2009; Smith and Tran, 2010; Black et al., 2011; Chambers et al., 2012; Sundermann et al., 2015) or in lakes (Graham et al., 2004; Free et al., 2006; Penning et al., 2008; Solheim et al., 2008; Soranno et al., 2008). Investigating different biological groups may either give more weight to an ecological threshold or reveal some uncertainty in its location, or even lead to the distinction between several thresholds. Similarly, the responses of the species in a same group can be analyzed separately. Following this approach, an ecological community threshold arises when several species appear sensitive to the same threshold (King and Baker, 2010).

Geographical thresholds in fish spatial distribution result from barriers to dispersal and historical events (Reyjol et al., 2007). Ecological thresholds related to water physicochemical parameters have been rarely assessed from fish assemblages. Water quality may directly create physiological stress and affect feeding or reproduction. Thresholds may appear as specific limits of tolerance. The existence of community thresholds assumes that several species share similar thresholds because they have the same ecological preferences or they replace each other in environmental gradients. In British Columbia (Canada), community temperature thresholds were derived from the analysis of river fish samples at 156 sites, marking large changes from very cold to cold and eventually cool water species (Parkinson et al., 2016). Another Canadian study showed that lake water acidity reduced fish diversity with a $\mathrm{pH}$ threshold between 5 and 5.5 (Tremblay and Richard, 1993). Shifts in fish communities along eutrophication or productivity gradients are well documented, with a general pattern of change from Salmoniformes to Percids and Cyprinids (Persson et al., 1991; Mehner et al., 2005).

A dense literature show responses of lake fish assemblages to nutrients, total phosphorus in particular (e.g. Argillier et al., 2013; Arranz et al., 2016), but most of the published works are based on the implementation of linear models (including transformation of the fish metrics). Using regression tree analyses (a non-linear method), several temperature and total phosphorus thresholds were highlighted from a study of European lakes considering community metrics (Brucet et al., 2013). Nevertheless, to our knowledge, thresholds of species distribution related to physico-chemical parameters were not clearly described in lakes. A possible explanation may be heterogeneous species distribution in such large scale analyses.

Considering the different physiological requirement of freshwater fish species encountered in the French lakes, our aim was to identify some thresholds in fish species response to physico-chemical parameters. Such thresholds can be helpful for the definition of ecologically relevant physicochemical standards required for the management of lakes in 
Table 1. Codes, units and distribution characteristics of the environmental variables considered in the analysis. For variables having annual variations (lines below Zmax), the first code corresponds to the annual median, the codes ending by "min" and "max" are the minimal and maximal annual values, respectively.

\begin{tabular}{|c|c|c|c|c|c|}
\hline Parameters & Codes & Units & Minimum & Median & Maximum \\
\hline Latitude & lat & ${ }^{\circ} \mathrm{N}$ & 42 & 45.8 & 50.1 \\
\hline Longitude & lon & ${ }^{\circ} \mathrm{E}$ & -4.2 & 2.3 & 9.5 \\
\hline Altitude & alt & $\mathrm{m}$ & 1 & 265 & 2061 \\
\hline Lake surface area & Surf & $\mathrm{km}^{2}$ & 1.1 & 1.91 & 57.6 \\
\hline Maximal depth & Zmax & $\mathrm{m}$ & 0.8 & 17.7 & 145 \\
\hline \multirow[t]{3}{*}{ Temperature - euphotic zone } & Temp & ${ }^{\circ} \mathrm{C}$ & 9.1 & 16.4 & 22.2 \\
\hline & Tempmin & ${ }^{\circ} \mathrm{C}$ & 1.1 & 6.0 & 18.6 \\
\hline & Tempmax & ${ }^{\circ} \mathrm{C}$ & 12.3 & 21.8 & 27.1 \\
\hline \multirow[t]{3}{*}{ Temperature - bottom } & TempB & ${ }^{\circ} \mathrm{C}$ & 4.1 & 11.3 & 20.0 \\
\hline & TempBmin & ${ }^{\circ} \mathrm{C}$ & 0.3 & 5.4 & 14.2 \\
\hline & TempBmax & ${ }^{\circ} \mathrm{C}$ & 4.2 & 16.6 & 27 \\
\hline \multirow[t]{2}{*}{ Secchi depth } & Secchi & $\mathrm{m}$ & 0.2 & 1.8 & 7.5 \\
\hline & Secchimin & ${ }^{\circ} \mathrm{C}$ & 0.1 & 1 & 6.7 \\
\hline \multirow[t]{2}{*}{$\mathrm{O}_{2}$ saturation - euphotic zone } & $\mathrm{SatO} 2$ & $\%$ & 57 & 95 & 154 \\
\hline & $\mathrm{SatO} 2 \mathrm{~min}$ & $\%$ & 15 & 75 & 107 \\
\hline \multirow[t]{2}{*}{$\mathrm{O}_{2}$ saturation - bottom } & SatO2B & $\%$ & 0 & 45 & 114 \\
\hline & SatO2Bmin & $\%$ & 0 & 1 & 94 \\
\hline Alkalinity & Alk & $\mathrm{meq} \cdot \mathrm{L}^{-1}$ & 0.1 & 0.9 & 4.6 \\
\hline \multirow[t]{3}{*}{$\mathrm{pH}$} & $\mathrm{pH}$ & - & 6.2 & 8.0 & 9.2 \\
\hline & pHmin & - & 5.1 & 7.4 & 8.4 \\
\hline & pHmax & - & 6.5 & 8.6 & 10.7 \\
\hline Conductivity & Cond & $\mu \mathrm{S} \cdot \mathrm{cm}^{-1}$ & 16 & 245 & 791 \\
\hline \multirow[t]{2}{*}{ Dissolved organic carbon } & DOC & $\mathrm{mg} \cdot \mathrm{L}^{-1}$ & 0.4 & 4.5 & 22.2 \\
\hline & DOCmax & $\mathrm{mg} \cdot \mathrm{L}^{-1}$ & 0.6 & 5.7 & 38 \\
\hline \multirow[t]{2}{*}{ Nitrates } & NO3 & $\mu \mathrm{g} \cdot \mathrm{L}^{-1}$ & 126 & 1900 & 42200 \\
\hline & NO3max & $\mu \mathrm{g} \cdot \mathrm{L}^{-1}$ & 410 & 5200 & 72000 \\
\hline \multirow[t]{2}{*}{ Ammonia } & NH4 & $\mu \mathrm{g} \cdot \mathrm{L}^{-1}$ & 6 & 50 & 461 \\
\hline & NH4max & $\mu \mathrm{g} \cdot \mathrm{L}^{-1}$ & 21 & 150 & 2450 \\
\hline \multirow[t]{2}{*}{ Nitrites } & $\mathrm{NO} 2$ & $\mu \mathrm{g} \cdot \mathrm{L}^{-1}$ & 4 & 24 & 260 \\
\hline & $\mathrm{NO} 2 \max$ & $\mu \mathrm{g} \cdot \mathrm{L}^{-1}$ & 6 & 60 & 940 \\
\hline \multirow[t]{2}{*}{ Phosphates } & PO4 & $\mu \mathrm{g} \cdot \mathrm{L}^{-1}$ & 6 & 16 & 515 \\
\hline & PO4max & $\mu \mathrm{g} \cdot \mathrm{L}^{-1}$ & 6 & 40 & 1590 \\
\hline \multirow[t]{2}{*}{ Total phosphorus } & $\mathrm{TP}$ & $\mu \mathrm{g} \cdot \mathrm{L}^{-1}$ & 6 & 27 & 425 \\
\hline & TPmax & $\mu g \cdot \mathrm{L}^{-1}$ & 10 & 45 & 1410 \\
\hline Dissolved silicon & $\mathrm{SiO} 2$ & $\mathrm{mg} \mathrm{SiO}{ }_{2} \cdot \mathrm{L}^{-1}$ & 0.2 & 3.4 & 20.8 \\
\hline
\end{tabular}

the context of WFD implementation (European Commission, 2000). More precisely, the objectives of this study were to evaluate (1) to what extent the variations in fish species biomass among French lakes can be explained by water physico-chemical parameters routinely measured in the WFD survey network, and (2) to investigate whether species relationships to environmental gradients reveal critical limits which could indicate ecological thresholds. To achieve this, a national database of fish biomass in French lakes was related to physico-chemical data. The exploratory method of gradient forest (Ellis et al., 2012) was chosen here owing to its ability to perform analyses on many species at the same time, and to take into account a lot of environmental factors and interactions among them. Combining the responses of each single species to any environmental gradient, it is particularly well suited for the identification of ecological community thresholds (Roubeix et al., 2016; Wagenhoff et al., 2017).

\section{Material and methods}

\subsection{Database}

\subsubsection{Fish data}

Fishes were sampled in French natural lakes and reservoirs between 2005 and 2014 using benthic multi-mesh gillnets according to Norden gillnet standardized protocol (CEN, 2005). Gillnets were $30 \mathrm{~m}$ long and $1.5 \mathrm{~m}$ high and composed of 12 different panels of uncolored nylon with mesh sizes ranging from 5 to $55 \mathrm{~mm}$ (knot to knot). They were left overnight $(12 \mathrm{~h})$ at random localizations in different depth strata of the lakes. The sampling effort, i.e. number of gillnets per night, was adjusted to lake depth and area following the recommendation of the standard (CEN, 2005). Fish sampling occurred between June and autumn, period where most of the species living in lakes do not spawn whereas their activity is still high. When epilimnion temperature drops below $15^{\circ} \mathrm{C}$, fish activity decreases and catches may decline. 


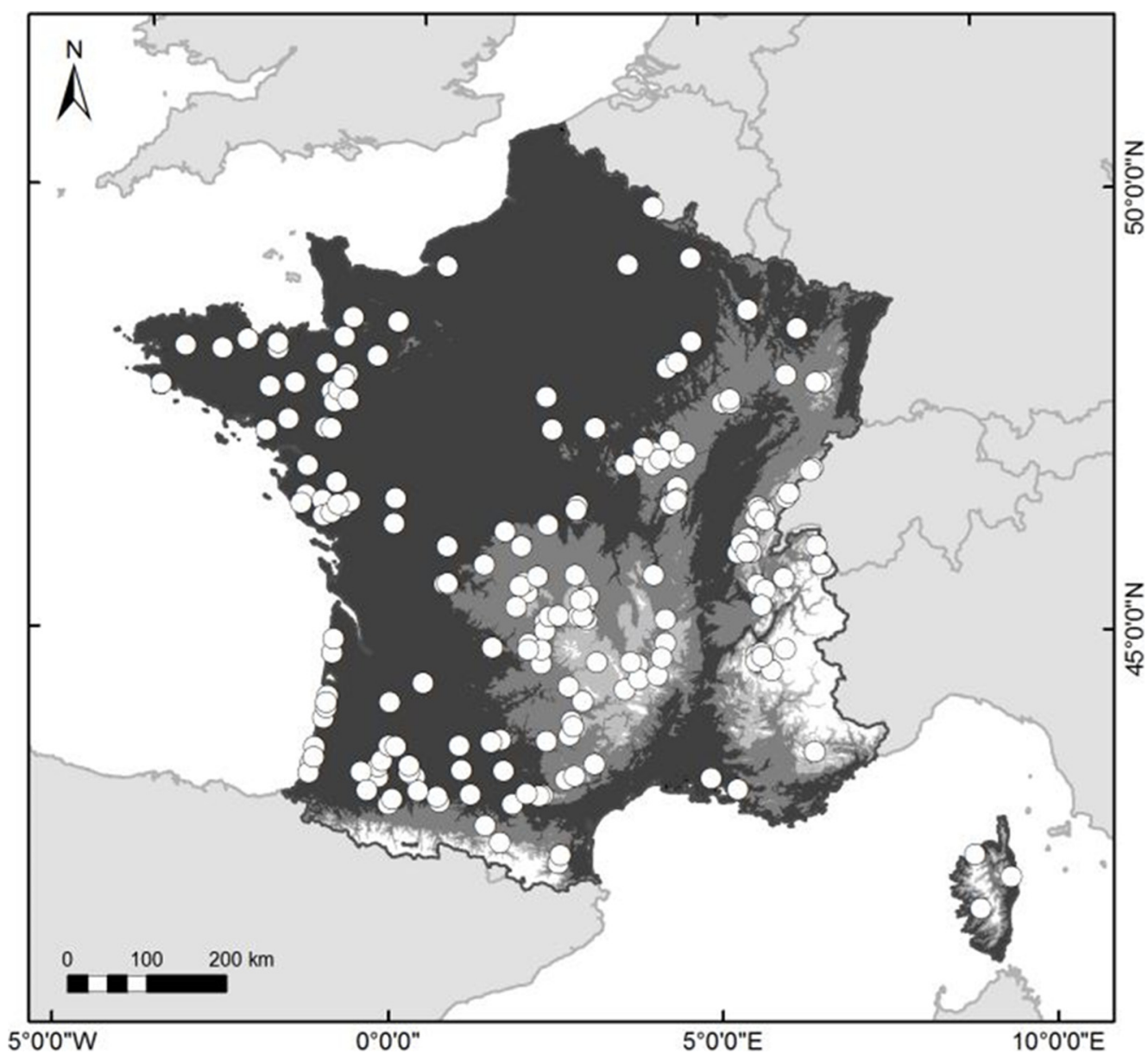

Fig. 1. Location of the sampled lakes used for gradient forest analysis ( $n=196$, elevation: dark grey $\geq 300 \mathrm{~m}$, light grey $\geq 800 \mathrm{~m}$, white $\geq 1300 \mathrm{~m}$, source: BD ALTI IGN).

Fish were identified at the species level, counted and weighted. In each lake, the species abundances were assessed by their biomass per unit effort (BPUE). Specific BPUE were calculated by dividing the total biomass of the species caught in the lake (in $\mathrm{g}$ ) by the sampling effort applied in the lake expressed in night $\cdot \mathrm{m}^{-2}$.

\subsubsection{Environmental data}

Environmental conditions were described by 36 variables (Tab. 1). Latitude, longitude, altitude, lake surface area and maximal depth were included in the analysis to account for species biogeography and lake diversity. The influence of the type of lake was also taken into account with a categorical variable (natural or reservoir). Water physico-chemical parameters were measured at the point of highest depth in each lake, following national and international standards (MEDDE, 2012; AFNOR, 2015). Data were collected at least during one year between 2004 and 2013, on the occasions of four seasonal campaigns. For each survey, mean values of temperature, $\mathrm{pH}$, conductivity and oxygen saturation were obtained from the integration of vertical profiles over the euphotic zone, whose lower limit was considered at 2.5 times Secchi depth (Koenings and Edmundson, 1991; Pourriot and Meybeck, 1995). In addition, temperature and oxygen saturation levels were considered at $1 \mathrm{~m}$ above the bottom of the lakes. Nutrients, dissolved organic carbon and alkalinity analyses were performed on an integrated water sample collected in the euphotic zone. Nutrient concentrations below the quantification limit (LQ) were given an arbitrary value of $\mathrm{LQ} / 2$ for data analysis. To characterize the environmental conditions of each lake, the median of the values from seasonal campaigns was retained, and the minimal and maximal values as well, for the parameters having high annual variability.

\subsection{Data analysis}

The analysis was performed on 196 lakes, including 44 natural lakes and 156 reservoirs. Aquaculture ponds and gravel pits were excluded because their fish populations were considered too manipulated. The lake sample is well distributed within the French territory with a good geographic coverage (Fig. 1). Only the species occurring in more than $3.5 \%$ of sampled lakes were kept for analysis because a minimal number of occurrences is required to elaborate specific models. This selection resulted in a final number of 25 fish species (Tab. 2), whose BPUE were used as response variables.

Gradient forest (Ellis et al., 2012) is an extension of random forest (Breiman, 2001) to address the responses of many species to environmental gradients. Gradient forest implies the construction of a random forest for each species of a survey. One output of random forest is the importance of each 
V. Roubeix et al.: Knowl. Manag. Aquat. Ecosyst. 2017, 418, 41

Table 2. List of the 25 fish species selected for gradient forest analysis. Their maximal BPUE estimated in sampled lakes and their percentage of occurrence among lakes are indicated. The codes are used to designate the species.

\begin{tabular}{|c|c|c|c|c|c|}
\hline Species & Common names & Native species & Codes & $\begin{array}{l}\text { Maximal BPUE } \\
\left(\mathrm{g} \cdot \text { night }^{-1} \cdot \mathrm{m}^{-2}\right)\end{array}$ & $\begin{array}{l}\% \text { Occurrence } \\
\text { (in natural lakes } \mathrm{N}, \\
\text { and reservoirs } \mathrm{R} \text { ) }\end{array}$ \\
\hline Abramis brama & Common bream & Yes & ABRABR & 3403 & $73,45(\mathrm{~N}), 82(\mathrm{R})$ \\
\hline Alburnus alburnus & Bleak & Yes & ALBUAL & 210 & $40,20(\mathrm{~N}), 45(\mathrm{R})$ \\
\hline Ameiurus melas & Black bullhead & No & AMEIME & 1698 & $24,20(\mathrm{~N}), 26(\mathrm{R})$ \\
\hline Barbatula barbatula & Stone loach & Yes & BARBBR & 9 & $5,2(\mathrm{~N}), 6(\mathrm{R})$ \\
\hline Blicca bjoerkna & White bream & Yes & BLICBJ & 5215 & $54,36(\mathrm{~N}), 59(\mathrm{R})$ \\
\hline Carassius carassius & Crucian carp & No & CARACA & 1167 & $12,7(\mathrm{~N}), 13(\mathrm{R})$ \\
\hline Coregonus sp. & Whitefish & Yes & CORESP & 491 & $9,36(\mathrm{~N}), 1(\mathrm{R})$ \\
\hline Cyprinus carpio & Common carp & Yes & CYPRCA & 2342 & $37,20(\mathrm{~N}), 41(\mathrm{R})$ \\
\hline Esox lucius & Northern pike & Yes & ESOXLU & 749 & $63,59(\mathrm{~N}), 64(\mathrm{R})$ \\
\hline Gobio gobio & Gudgeon & Yes & GOBIGO & 1475 & $17,32(\mathrm{~N}), 12(\mathrm{R})$ \\
\hline Gymnocephalus cernuus & Ruffe & Yes & GYMNCE & 477 & $55,41(\mathrm{~N}), 59(\mathrm{R})$ \\
\hline Lepomis gibbosus & Pumpkinseed & No & LEPOGI & 45 & $30,32(\mathrm{~N}), 30(\mathrm{R})$ \\
\hline Leucaspius delineatus & Belica & Yes & LEUCDE & 232 & $6,2(\mathrm{~N}), 7(\mathrm{R})$ \\
\hline Leuciscus leuciscus & Common dace & Yes & LEUCLE & 57 & $5,5(\mathrm{~N}), 5(\mathrm{R})$ \\
\hline Oncorhynchus mykiss & Rainbow trout & No & ONCOMY & 853 & $9,14(\mathrm{~N}), 8(\mathrm{R})$ \\
\hline Perca fluviatilis & European perch & Yes & PERCFL & 3605 & 93, 91(N), 93(R) \\
\hline Phoxinus phoxinus & Eurasian minnow & Yes & PHOXPH & 49 & $4,7(\mathrm{~N}), 3(\mathrm{R})$ \\
\hline Rutilus rutilus & Roach & Yes & RUTIRU & 4633 & $95,95(\mathrm{~N}), 95(\mathrm{R})$ \\
\hline Salmo trutta & Common trout & Yes & SALMTR & 1455 & $13,23(\mathrm{~N}), 11(\mathrm{R})$ \\
\hline Salvelinus umbla & Lake char & Yes & SALVUM & 135 & $4,18(\mathrm{~N}), 0(\mathrm{R})$ \\
\hline Sander lucioperca & Pike-perch & No & SANDLU & 1907 & $75,50(\mathrm{~N}), 82(\mathrm{R})$ \\
\hline Scardinius erythrophthalmus & Rudd & Yes & SCARER & 2120 & $75,89(\mathrm{~N}), 71(\mathrm{R})$ \\
\hline Silurus glanis & European catfish & No & SILUGL & 1500 & $17,9(\mathrm{~N}), 19(\mathrm{R})$ \\
\hline Squalius cephalus & Chub & Yes & SQUACE & 1452 & $30,41(\mathrm{~N}), 27(\mathrm{R})$ \\
\hline Tinca tinca & Tench & Yes & TINCTI & 1296 & $37,64(\mathrm{~N}), 29(\mathrm{R})$ \\
\hline
\end{tabular}

environmental variable in the prediction of the biomass of a species. For every species, gradient forest distributes the specific importance of each variable along the corresponding gradient. The results can be represented with monotonic curves of specific cumulative importance, increasing along the gradients up to the total variable importance. Steep slopes or steps of the curves indicate zones in the gradients where the variables have more importance. In terms of regression tree analysis, a variable gains importance locally when its value separates a group of specific biomass data into two more homogeneous groups. The increase in importance depends on the deviance reduction (i.e. decrease in residual sums of squares) due to the split. Thus, a local increase of importance might indicate a threshold marking a considerable change in the BPUE of a species. Cumulative importance plots allow to visualize the importance and abruptness of specific thresholds detected and to highlight common threshold locations among species.

Gradient forest was run using the two $\mathrm{R}$ packages "extended-Forest" and "gradientForest" (Ellis et al., 2012; R Core Team, 2013). A total of 500 trees were generated for each random forest. Individual variable importance was estimated using constrained permutations to reduce the influence of correlated variables (correlation coefficient $>0.5$ ) (Strobl et al., 2008; Ellis et al., 2012). As required for regression tree analysis (De'ath and Fabricius, 2000), the variance of BPUE data was stabilized using a log-transformation after addition of the minimal strictly positive value for each species. Local regression was applied to strictly positive raw BPUE data using R "lowess" function (smoother $\operatorname{span}=2 / 3$ ). In order to calculate a probability of presence, the numbers of measurements and occurrences in 201 bins of each gradient were first determined. Then, the variations of these numbers were smoothed using $\mathrm{R}$ density function with a Gaussian kernel and the bandwidth determined by the gradient forest package for the density of data. Finally, the density of occurrences was divided by the density of measurements to give a probability of presence along the gradient.

\section{Results}

The most sampled species were roach Rutilus rutilus, European perch Perca fluviatilis, pike-perch Sander lucioperca and common bream Abramis brama (Tab. 2). The highest specific biomasses were recorded for white bream Blicca bjoerkna, roach and European perch. Some species were found almost exclusively in natural lakes (whitefish Coregonus sp. and lake char Salvelinus umbla) whereas others showed preference for reservoirs (common bream, pike-perch, bleak Alburnus alburnus and common carp Cyprinus carpio). Species considered non-native were black bullhead Ameiurus 
melas, crucian carp Carassius carassius, pumpkinseed Lepomis gibbosus, rainbow trout Oncorhynchus mykiss, pike-perch and European catfish Silurus glanis.

The results of gradient forest analysis indicated that the variations in biomass of five species, namely common carp, crucian carp, belica Leucaspius delineatus, dace Leuciscus leuciscus and European catfish could not be explained at all by the 36 environmental variables used (Fig. 2). These species had null or negative $R^{2}$ (a numerical possibility with gradient forest), and were therefore not taken into account for the detection of thresholds in the environmental gradients. Considering the 20 other species, the maximal $R^{2}$ value was 0.53 and the average was 0.22 (Fig. 2) which means that the environmental variables explained only a moderate part of species variance in BPUE. The best predicted species were in decreasing order whitefish (CORESP), brown trout (SALMTR), white bream (BLICBJ), pike-perch (SANDLU), chub (SQUACE) and common bream (ABRABR).

The variables which explained the most species variance, i.e. the most important predictors for each species as estimated by random forest, could be clearly identified (Fig. 3). The biomass of brown trout (SALMTR) was largely determined by Tempmax and was negatively correlated to this variable (Spearman correlation coefficient, $\rho=-0.37$ ). The biomass of white bream (BLICBJ) was mostly dependent on latitude, with higher values in the northern part of France $(\rho=0.46)$. Particularly, it appeared that DOC and Secchi were important physico-chemical parameters, especially for minnow (PHOXPH) and stone loach (BARBBR), and common bream (ABRABR) and tench (TINCTI).

Considering all fish species together, environmental variables can be classified according to their community scale importance, which is a $R^{2}$ weighted average of the specific importance (Fig. 4). The most important variables were Tempmax followed by the geographic variables latitude and longitude, DOC and altitude. A step below $(<0.01)$ were less important explanatory variables including notably Secchi and far below TP and NO3.

Focusing on each variable separately, gradient forest revealed locations of potential thresholds in the response of fish species to the gradient and emphasized the emergence of common thresholds among species. Results are shown in Figures 5-7 for the most important variables and for NO3 and TP. Indeed, the two latter variables exhibited some thresholds after gradient forest analysis. Along with Secchi depth, they generally reflect the eutrophication process. For each variable, a specific cumulative importance plot reveals which species contributed to a common threshold. The BPUE of two of these species were plotted along the gradient for illustration.

Regarding the gradient of Tempmax (Fig. 5), a clear threshold appeared for brown trout (SALMTR) at $c a .18^{\circ} \mathrm{C}$. To a lesser extent, this threshold also influenced minnow (PHOXPH), roach (RUTIRU) and stone loach (BARBBR). Other thresholds were also visible at $20^{\circ} \mathrm{C}$ for common bream (ABRABR) and pike-perch (SANDLU) and around $22^{\circ} \mathrm{C}$ for black bullhead (AMEIME) and common carp (CYPRCA). Above the threshold of $18^{\circ} \mathrm{C}$, the biomass and the probability of presence of brown trout (SALMTR) decreased and minnow (PHOXPH) was almost absent.

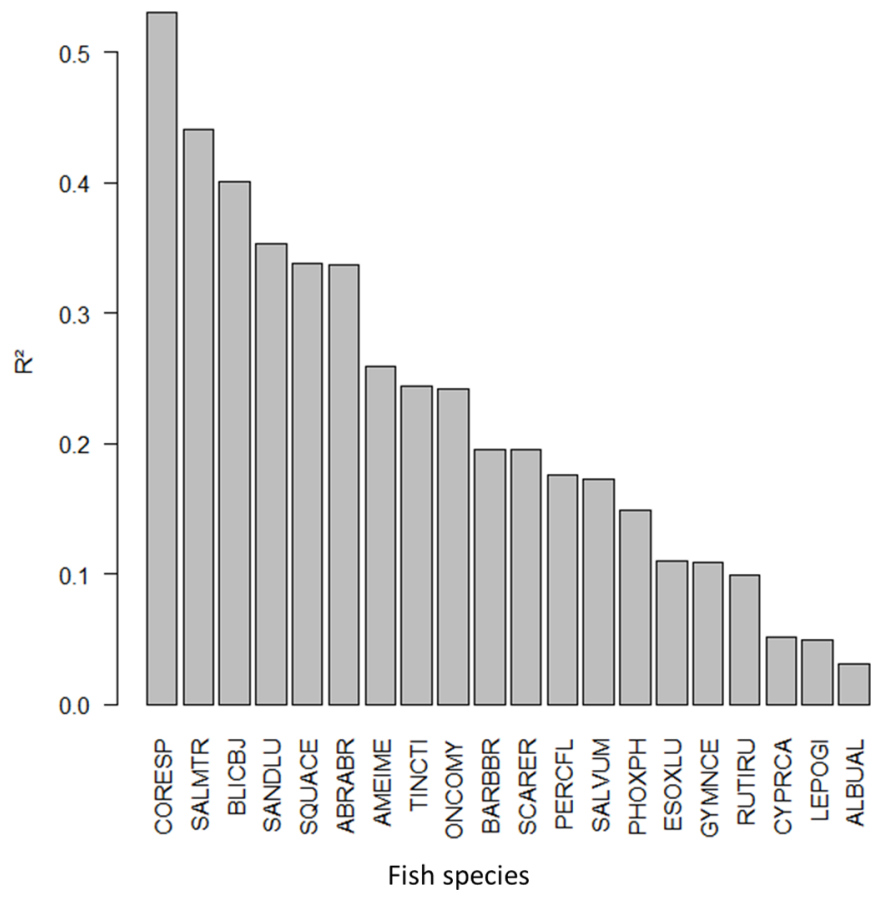

Fig. 2. Overall performance $\left(R^{2}\right)$ of random forests over species. Species with $R^{2} \leq 0$ are not represented.

The specific cumulative importance of DOC suggests that this parameter may affect the biomass of many species, but at different levels in the gradient. Nevertheless, several species seemed to be sensitive to a threshold located between 1 and $2 \mathrm{mg} \cdot \mathrm{L}^{-1}$. This was especially the case for stone loach (BARBBR) and European perch (PERCFL) showing opposite variations in BPUE around a value of $1.3 \mathrm{mg} \cdot \mathrm{L}^{-1}$. For stone loach (BARBBR), a sharp decrease in probability of presence was also observed above this threshold.

Secchi had similar cumulative importance curves for the species pike-perch (SANDLU), common bream (ABRABR), white bream (BLICBJ) and whitefish (CORESP) (Fig. 6). A common threshold appeared around $3 \mathrm{~m}$, above which the probability of presence of pike-perch (SANDLU) and common bream (ABRABR) decreased, whereas their BPUE more gradually dropped from the threshold onwards. In the gradient of NO3, two common thresholds were detected at 700 (SQUACE and SALVUM) and $2000 \mu \mathrm{g} \cdot \mathrm{L}^{-1}$ (ABRABR, ALBUAL and SALMTR). The latter was characterized by a steep increase in probability of presence of common bream (ABRABR) and an opposite trend for brown trout (SALMTR).

Gradient forest analysis detected two thresholds in the TP gradient located around 13 and $30 \mu \mathrm{g} \cdot \mathrm{L}^{-1}$. Both corresponded to changes in biomass of several species (Fig. 7). Pike-perch (SANDLU) and tench (TINCTI) defined the second threshold. They showed opposite responses to the gradient. Pike-perch (SANDLU) occurred more often in phosphorousrich waters while tench (TINCTI) displayed an opposite trend. The threshold was characterized by an important change in probability of presence of both species and slight variations in their BPUE. 
V. Roubeix et al.: Knowl. Manag. Aquat. Ecosyst. 2017, 418, 41

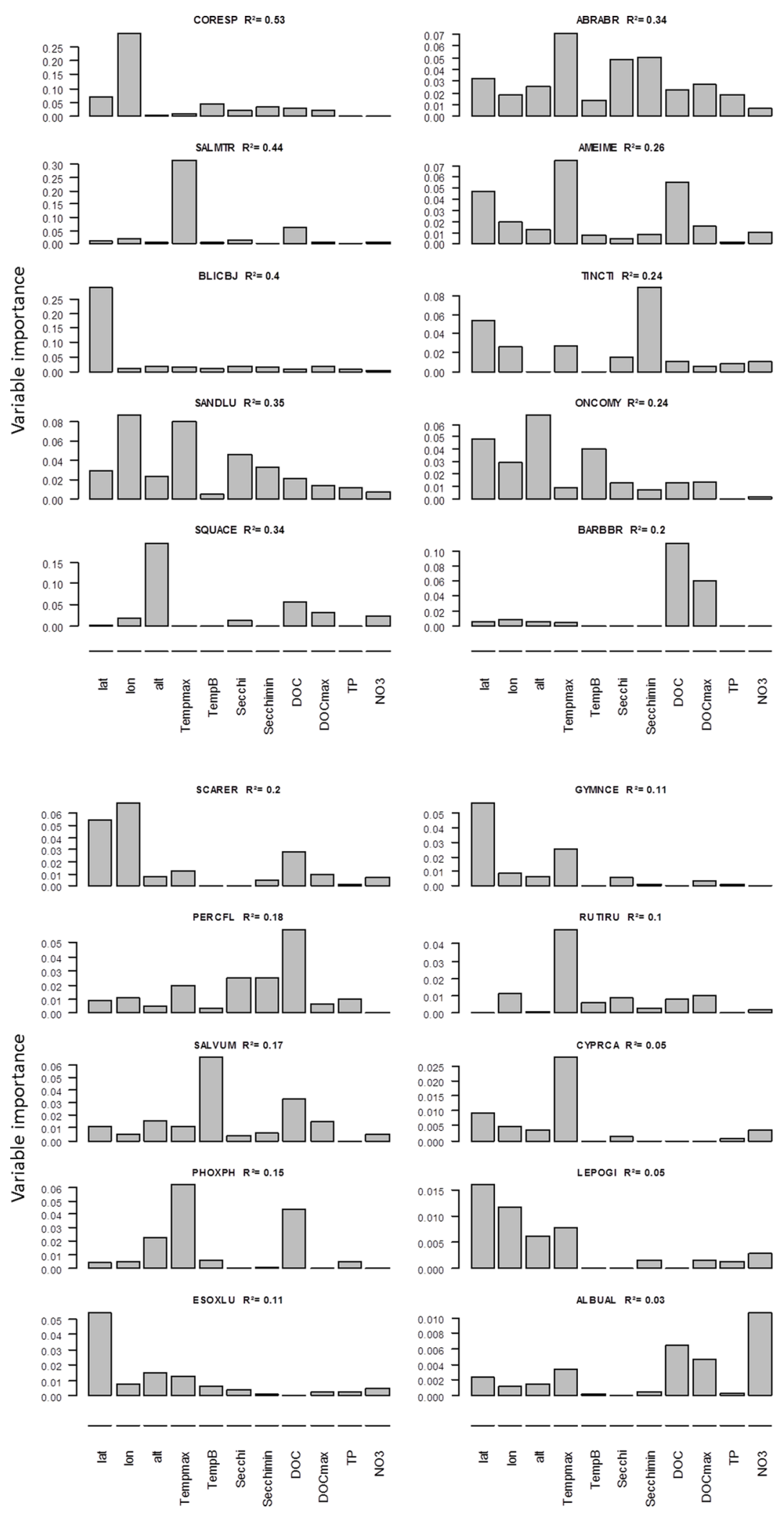

Fig. 3. Accuracy importance of the 9 most important environmental variables and the two variables NO3 and TP, for each species. Values are normalized to sum to the specific $R^{2}$. 


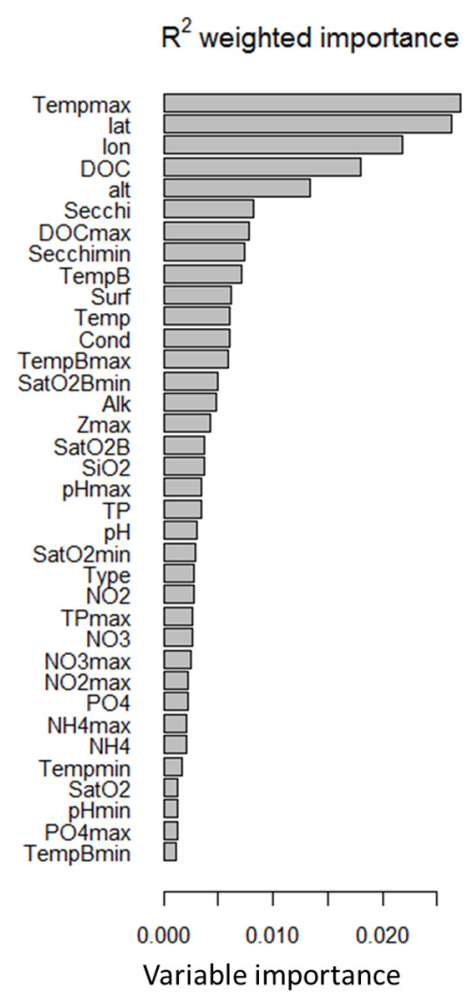

Fig. 4. Overall importance of the environmental variables for all the fish species, normalized to sum to the average specific $R^{2}(0.22)$.

\section{Discussion}

\subsection{Methodological considerations}

Gradient forest is a well suited exploratory method for the detection of ecological thresholds from large databases involving numerous species and environmental variables (Ellis et al., 2012; Pitcher et al., 2012; Roubeix et al., 2016). Among the numerous thresholds that have been identified herein, three criteria may be used to select the ecologically most significant ones: (1) the variable concerned is generally important for all considered species (Fig. 4), (2) the threshold is clearly defined in the gradient, i.e. high step in the specific cumulative importance curve, and (3) several species are sensitive to the same threshold. In this study, the gradient forest analysis highlighted common thresholds for several species in response to Tempmax (Fig. 5) and Secchi (Fig. 6) variables.

The performance of gradient forest may be lower in case of linear relationships between the biota and its environment. The method of data splitting in gradient forest is based on variance reduction and may produce spurious thresholds in case of linearity (Daily et al., 2012). Although species-environment relationships are often nonlinear (Terbraak and Verdonschot, 1995), it is useful in addition to the multivariate analysis, to examine graphically the plots of species biomass in gradients, as was done in this study. However, thresholds may not appear clearly on such single plots since in gradient forest, splits are generally done on partitions of the data and not on the whole dataset.

Another limitation of the analysis made in this study which is related to its large scale application, is the impossibility to take into account the rarest species in the dataset. In fact, half of the 50 species present in the French national database were not considered in the gradient forest analysis. Since a minimal number of occurrences is required for the identification of meaningful thresholds (a limit of 7 occurrences was set here), species having a too sparse distribution among the sampled sites cannot contribute to the definition of community thresholds, although they might be ecologically relevant in a local or site-specific approach.

In spite of the large number of explanatory variables considered, the performance of random forests was generally low to predict the biomasses of the 25 species (Fig. 2). Species biomass could be also better explained if descriptors of fish physical habitat were taken into account in the analysis. The inclusion of lake hydromorphological features such as the system size, substrate, macrophyte cover, ripisylve fragmentation or water level range, could improve the performance of the analysis. The basic morphological variables used here (maximal depth, lake area and type of lake) had only a limited influence on fish biomass (Fig. 4). The knowledge of species manipulation in each lake would also allow a refined interpretation of the variations in biomass in particular for the species with angling and fishing interest. Unfortunately, such morphological and human impacted factors were difficult to obtain for the whole lake dataset.

Hysteresis implies that a threshold in a gradient may change according to the direction in which an ecosystem evolves (degradation or restoration) (Andersen et al., 2009). It may be a source of uncertainty in the definition of a threshold which is not possible to evaluate with the analysis conducted here. As the number of lakes in our database which are currently getting restored is probably very low, the thresholds identified in this study rather represent protection limits that should not be exceeded. They may differ considerably from restoration targets in case of hysteresis (Solheim et al., 2008).

\subsection{Important factors and thresholds}

\subsubsection{Water temperature}

Maximal annual temperature appeared here as the most structuring physico-chemical parameter for fish assemblages (Fig. 4). The identified temperature thresholds (18, 20 and $22^{\circ} \mathrm{C}$ ) may appear relatively close to each other from a purely physical point of view. However, fish are poikilotherms and are therefore sensitive to changes in thermal conditions of their environment. Temperature has a direct effect on fish activity, growth, metabolism, reproduction and development but can also influence communities and populations via biotic interactions (Petchey et al., 1999; Voigt et al., 2003; O'Connor et al., 2009; Rall et al., 2010; Yvon-Durocher et al., 2010; Ohlberger et al., 2011; Vucic-Pestic et al., 2011; Reuman et al., 2014). From this viewpoint, $1-3{ }^{\circ} \mathrm{C}$ increase in temperature due to global warming have been shown to have major impacts on fish community structure and diversity (Daufresne et al., 2004, 2009; Daufresne and Boet, 2007). Temperate species generally avoid water warmer than $30^{\circ} \mathrm{C}$ and the temperature preference is a commonly used criterion to classify fish into cold and warm water species (Holcik et al., 1989; Wehrly et al., 2003). Maximal annual temperature was particularly influent on the BPUE of brown trout which is adapted to cold water (Crisp, 1996; Rahel and Nibbelink, 1999). A threshold of $c a$. 

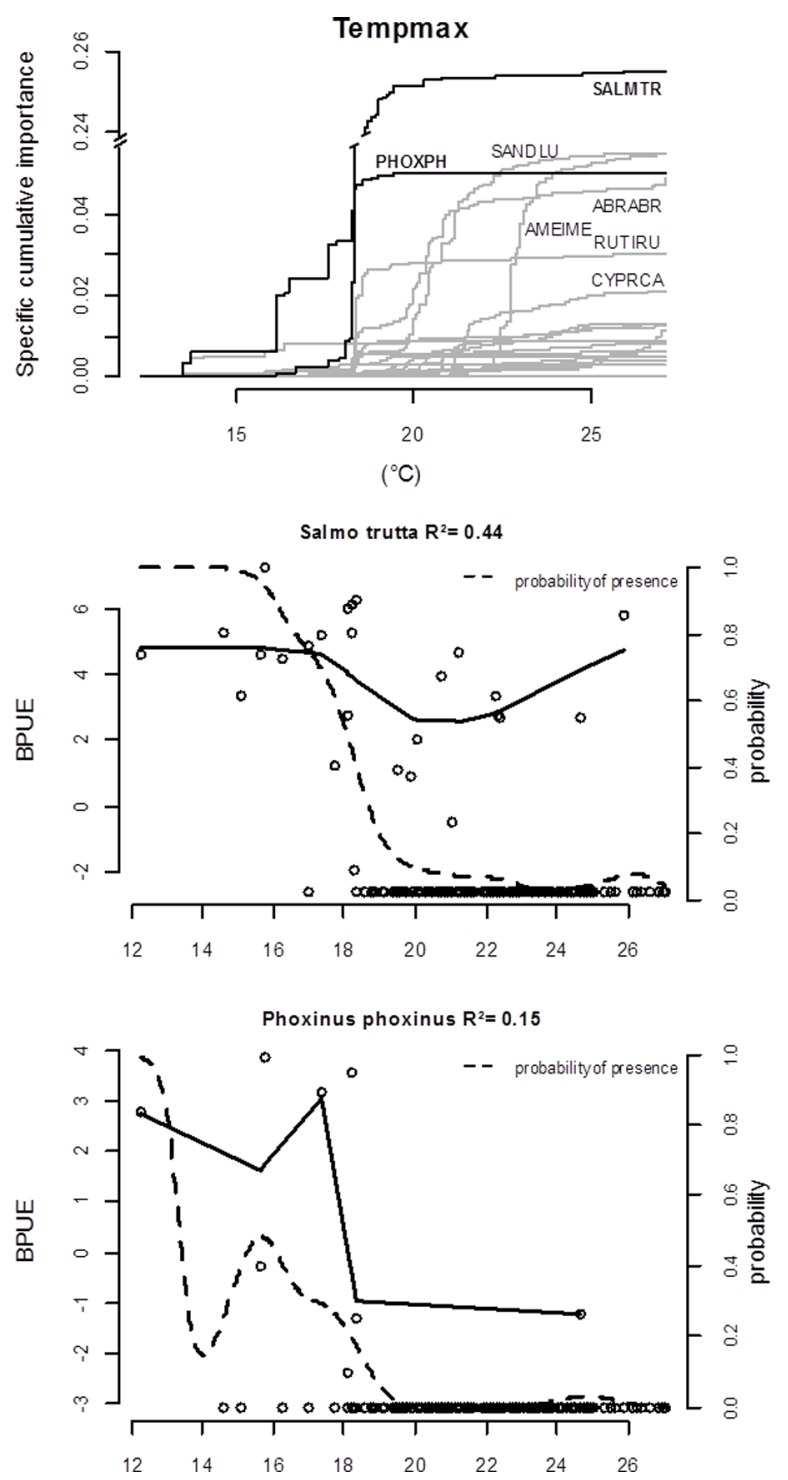
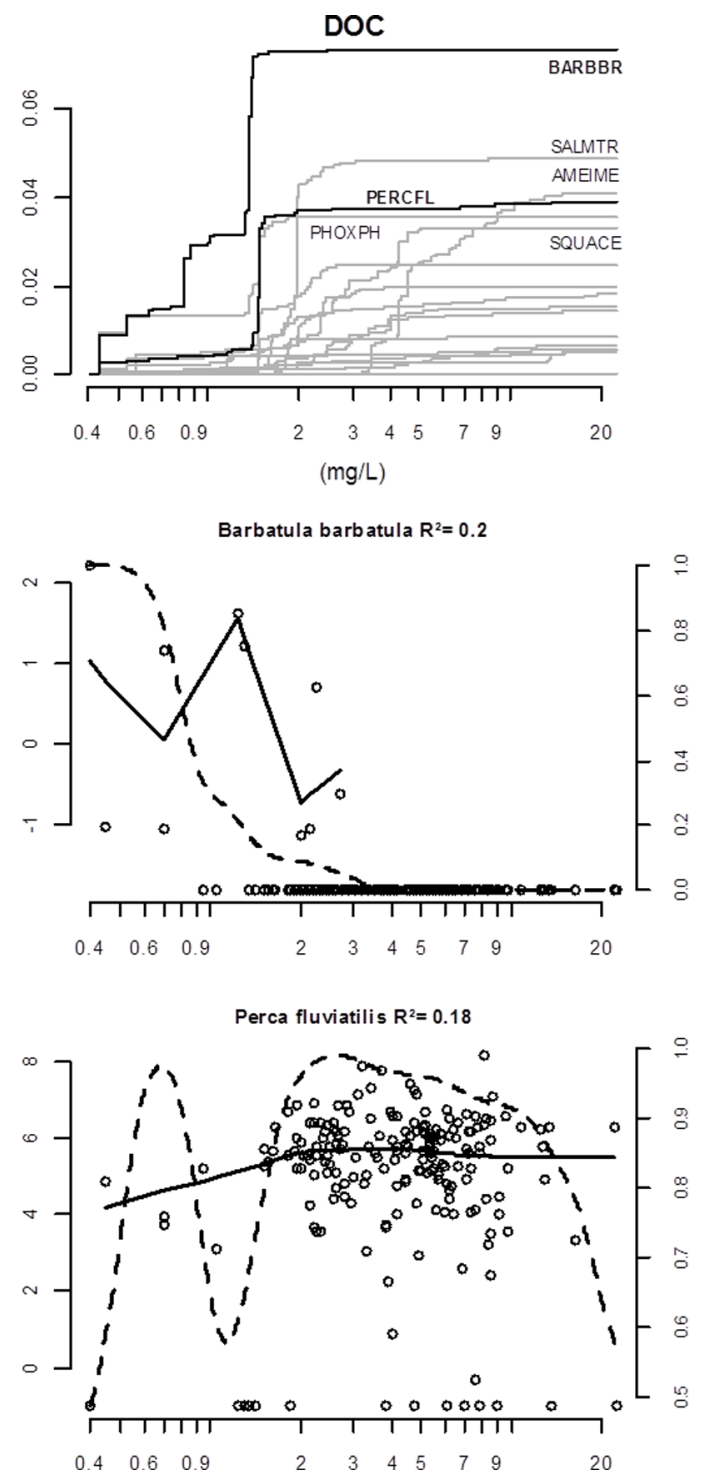

Fig. 5. Results of gradient forest for maximal water temperature (Tempmax, left column) and dissolved organic carbon (DOC, right column, log scale). The specific cumulative importance indicates the locations of potential thresholds in the responses of fish species to the gradients (note the offset of the $y$-axis for Salmo trutta). The BPUE of four species are shown as examples: Salmo trutta and Phoxinus phoxinus for Tempmax and, Barbatula barbatula and Perca fluvatilis for DOC. Plain lines are local regressions on strictly positive BPUE values and dashed lines are probabilities of presence along the gradients.

$18^{\circ} \mathrm{C}$ was identified for brown trout, minnow and stone loach with very low BPUE of these species above this temperature (Fig. 5). These results are in accordance with the $7-19^{\circ} \mathrm{C}$ optimal temperature range given by Bruslé and Quignard (2001) for brown trout. Minnow and stone loach are cold water species inhabiting similar zones than brown trout and having upper values of their temperature ranges near $18^{\circ} \mathrm{C}(20$ and $18^{\circ} \mathrm{C}$ for minnow and loach, respectively, FishBase, 2016). The value of $18^{\circ} \mathrm{C}$ is close to the community threshold of $19^{\circ} \mathrm{C}$ identified by Parkinson et al. (2016) from fish communities of Canadian streams, separating cold from cool water assemblages. It is also comparable to the maximal temperature threshold of $15.7^{\circ} \mathrm{C}$ found by Brucet et al. (2013) as a major split value to explain fish diversity in European lakes by a regression tree analysis.
A different threshold at $20^{\circ} \mathrm{C}$ was found for species tolerating warmer conditions (e.g. pike-perch and common bream) (Fig. 5), with low BPUE below and high BPUE above this temperature $(\mathrm{S} 3)$. Optimal temperature ranges of pikeperch and common bream are $27-30{ }^{\circ} \mathrm{C}$ and $10-26^{\circ} \mathrm{C}$, respectively (Souchon and Tissot, 2012). Although these species have clear preferences for warmer temperature than brown trout, minnow and stone loach, it is thus still unclear why a marked shift in BPUE at $20^{\circ} \mathrm{C}$ was observed. Finally, a specific threshold at $22^{\circ} \mathrm{C}$ was defined from the variations in the biomass of black bullhead, which can reproduce only in water warmer than $20^{\circ} \mathrm{C}$ (Mann, 1996; Keith and Allardi, 2001; Wolter, 2007) and has very high tolerance for temperature above $30^{\circ} \mathrm{C}$ (Bruslé and Quignard, 2001; FishBase, 2016). 


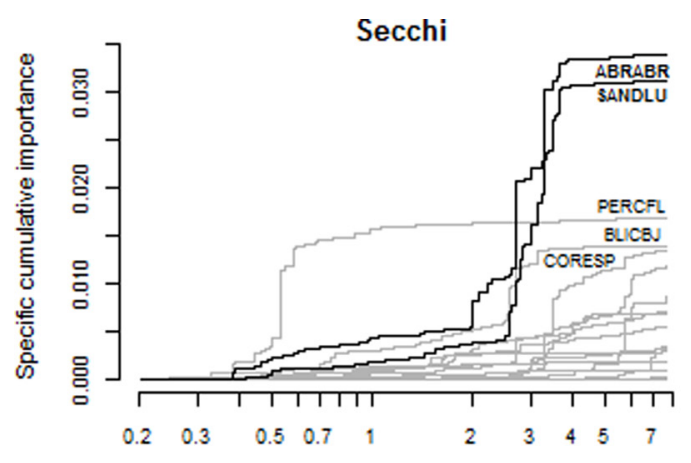

(m)
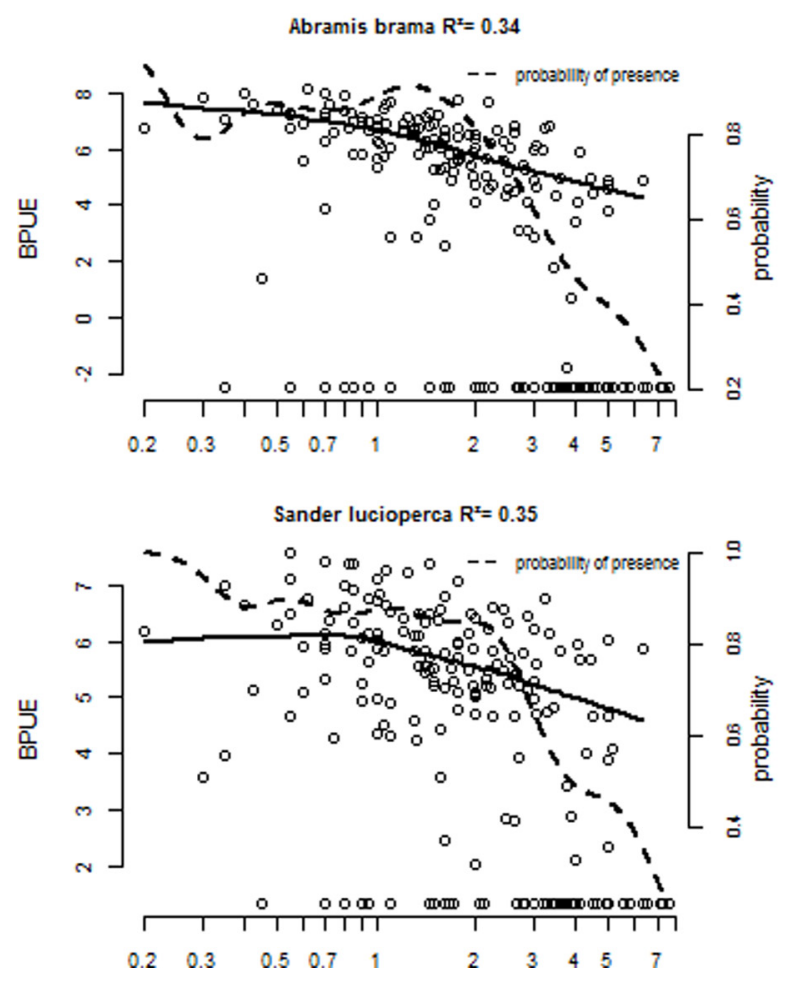
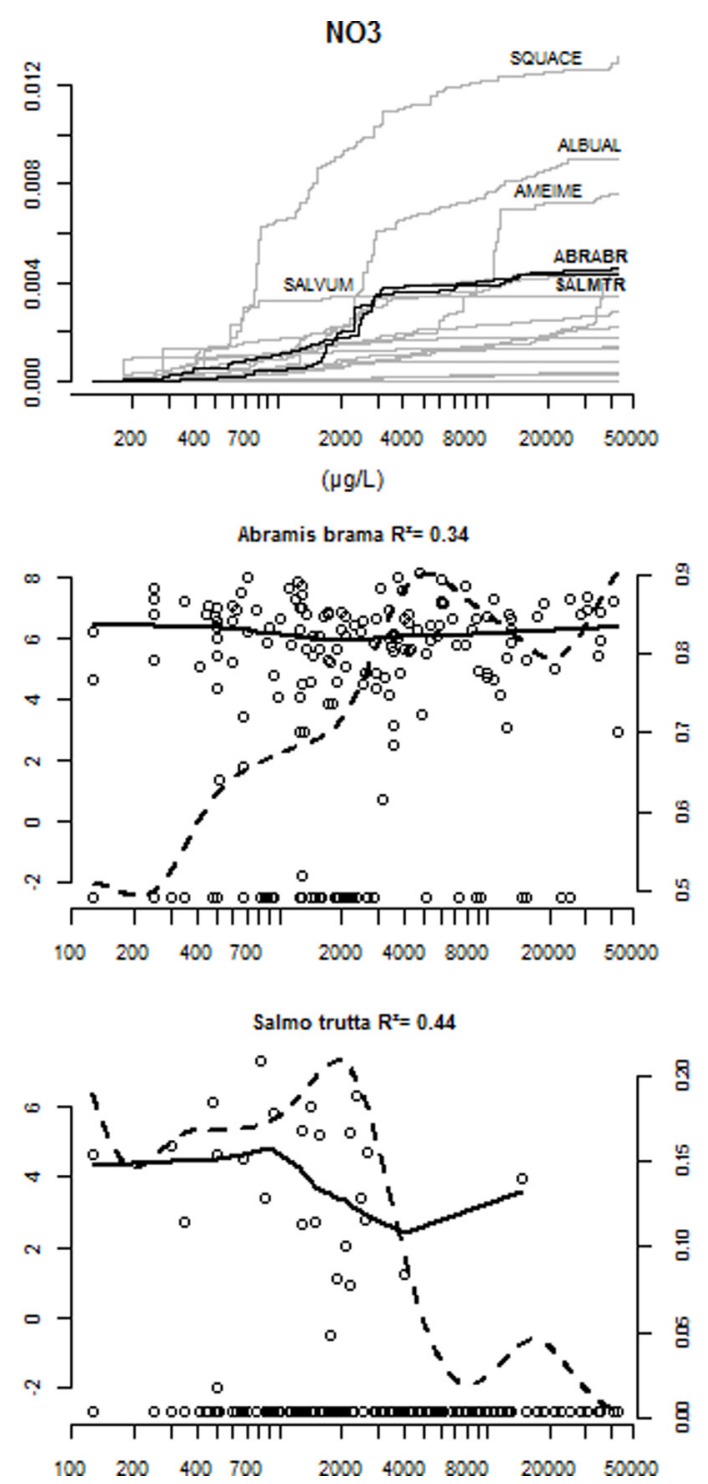

Fig. 6. Results of gradient forest for Secchi depth (Secchi, left, log scale) and median nitrate concentration (NO3, right, log scale). The specific cumulative importance indicates locations of potential thresholds in the responses of the different fish species to the gradients. Examples of fish responses are provided with Sander lucioperca and Salmo trutta for Secchi and NO3, respectively, and with Abramis brama for both variables. Plain lines are local regressions on strictly positive BPUE values and dashed lines are probabilities of presence along the gradients.

Our results are globally consistent with the current knowledge regarding the temperature preferences of European species. Temperatures close to the upper limit of the thermal range of a species represent a high risk of direct mortality for individuals (Daufresne et al., 2015). Besides mortality rates, many other life-history traits are temperature dependent. This is especially the case for reproduction related traits, and fish populations and community dynamics are known to be strongly influenced by reproduction temperature (Grenouillet et al., 2001; Nunn et al., 2002; Daufresne et al., 2004, 2015; Daufresne and Boet, 2007). It sounds likely that the use of seasonal temperature variables based on continuous temperature sampled over the water column would improve the performance of our models.
The close thresholds related to water temperature have to be considered carefully. Lake water temperature is going to increase in the future as a consequence of global warming and the definition of thresholds for management are particularly needed in this context (Liu et al., 2015). Although the mitigation of climate changes in natural lakes is difficult at local scale, water temperature can be to some extent modified by adapted water withdrawal regimes or by thermal discharge from power plants or industry. The threshold of $18^{\circ} \mathrm{C}$ represents a risk of dramatic reduction, or extinction, of cold water species, especially brown trout. The secondary threshold of $20^{\circ} \mathrm{C}$ marks the development of other species adapted to higher temperature. Reaching the $22^{\circ} \mathrm{C}$ limit may trigger the proliferation of opportunist and non-native species such as black bullhead. 

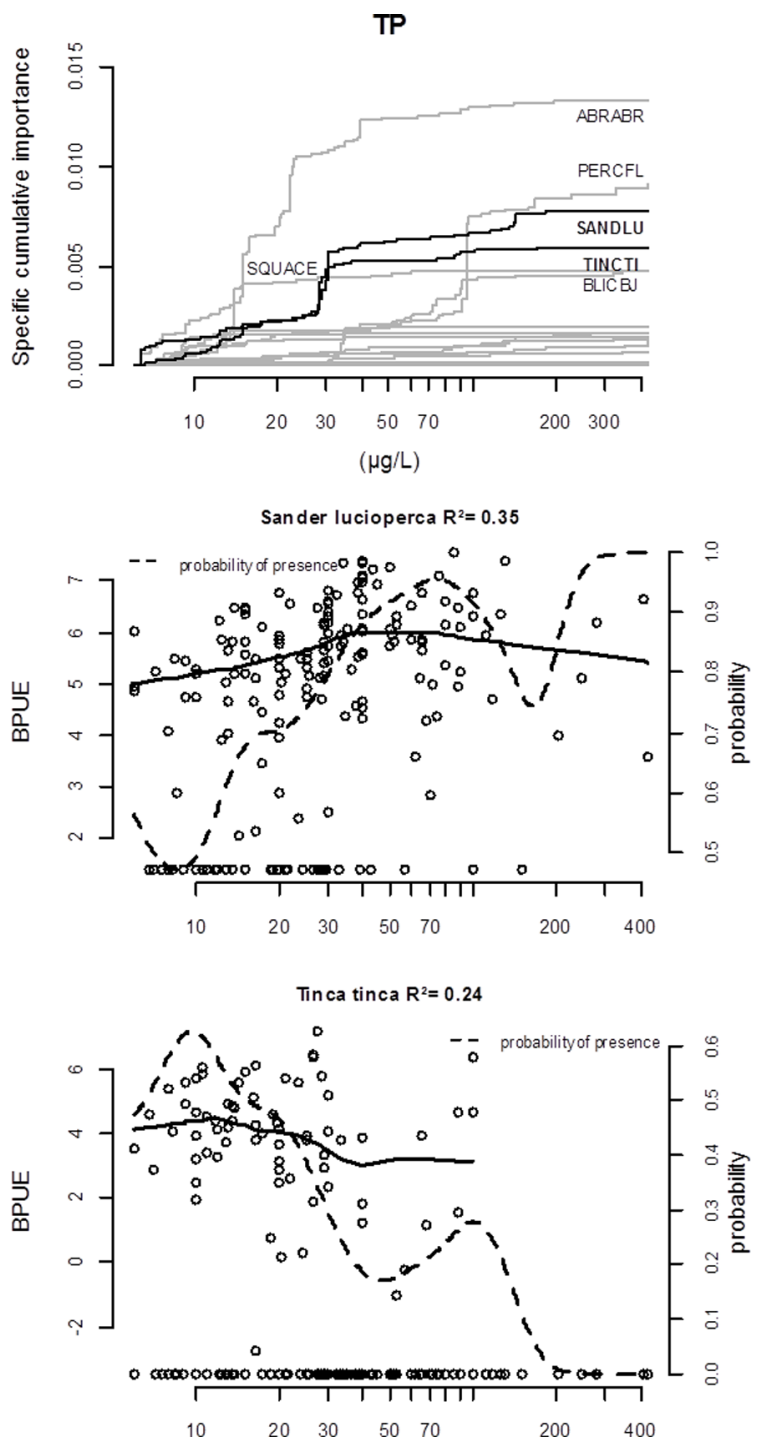

Fig. 7. Results of gradient forest for total phosphorus (TP, log scale). The specific cumulative importance indicates locations of potential thresholds in the responses of the different fish species to the gradients. Specific responses of Sander lucioperca and Tinca tinca are shown as examples. Plain lines are local regressions on strictly positive BPUE values and dashed lines are probabilities of presence along the gradients.

\subsubsection{Geographical factors}

A striking result of the gradient forest analysis was the high global importance of the spatial variables (latitude, longitude and altitude). This can be explained by the occurrences or higher abundances of some species in restricted geographic areas. Such spatial distribution patterns can be due to historical events and migration processes, or they might reflect correlations with temperature or particular environmental conditions which cannot be accounted for by any of the explanatory variable considered in the analysis. For example, following the last glaciations, whitefish, a typically lentic species, only maintained in deep subalpine lakes (near longitude $6^{\circ} \mathrm{E}$ ) in which it could find a persistent cold water layer under the thermocline (Pourriot and Meybeck, 1995). In terms of abundance, fish spatial distributions also generally vary according to an altitudinal gradient. Isolated lakes in high mountains (Alps in the East, Pyrenees in the South-West) usually present a very low fish diversity with low densities (Argillier et al., 2002; Irz et al., 2002), while downstream lake systems, more shallow, warmer and more productive, have generally both higher fish diversity and densities (Downing and Plante, 1993; Brucet et al., 2013). The higher biomass of white bream in the northern part of France above $46.5^{\circ} \mathrm{N}$ and the clear preference of chub for lakes above $300 \mathrm{~m}$ were not expected results (S2). The latter result is particularly surprising since chub is common in rivers downstream and can stand high temperatures (Keith et al., 2011). But chub is lithophil (Balon, 1975) and thus requires running waters with stones for reproduction, conditions which may be rarely found in close connections to low elevation lakes. The causes of these particular distributions have to be further investigated. This example suggests that taking into account lake connections to the river network may improve the modelling of species distribution.

\subsubsection{Other parameters}

DOC is an important indicator of lake functioning (Williamson et al., 1999). It reflects the input of organic matter from the watershed and internal production. DOC has many effects on lake ecosystems; it is therefore difficult to identify direct links between its concentration and the biomass of the different fish species (Fig. 5). Among other effects, an increase of organic carbon concentration in a lake modifies the food-web structure (Blomqvist et al., 2001) and may particularly affect fish assemblages. Moreover, DOC represents a risk of oxygen depletion which impacts differently fish species. Non-linear relationships between fish species and DOC have already been demonstrated in lakes (Finstad et al., 2014). In this study, except European perch which exhibited a preference for higher DOC levels, the biomass of all species sensitive to a DOC threshold were higher at lower concentrations (S3). DOC concentration naturally varies among lakes and is particularly high in lakes of the humic type. However, its concentration also depends on human activities via agriculture and waste water discharge. DOC may increase as a result of eutrophication as suggested by the correlation between TP and DOC in the dataset $(\rho=0.66, \mathrm{~S} 1)$. Thus, a limit of DOC between 1.2 and $2 \mathrm{mg} \cdot \mathrm{L}^{-1}$ might be used for the preservation of lakes presenting low natural DOC concentrations.

Like DOC, water transparency (Secchi) is an integrative parameter related to the colored part of DOC but also to the suspended matter that depends on sediment input or resuspension and on lake productivity (Carlson, 1977; Megard et al., 1980). The gradient forest analysis revealed a Secchi depth limit of $c a .3 \mathrm{~m}$ separating whitefish which is associated to clear water, to common bream, white bream and pike-perch which accommodate well to turbid waters (Fig. 6). The bream species are benthic feeders which generate themselves turbid conditions by sediment resuspension when feeding, and pikeperch is a sight predator whose vision is well adapted to turbid water (Keith et al., 2011). Secchi depth gives an indication of the lake trophic state if water color and inorganic sediment concentration are low (Megard et al., 1980). This might be generally the case for French lakes considering the high correlation between Secchi and TP $(\rho=-0.78)$. The boundary of $3 \mathrm{~m}$ arising from the variations in biomass of several species 
(Fig. 6) seems important to account for in lake ecological assessment. This threshold corresponds to the mesotrophiceutrophic limit in the OECD diagnostic model (OECD, 1982).

The accumulation of nutrients leads to eutrophication which is a major cause of lake degradation by human activities. However, the importance of NO3, TP, NO2 and NH4 was relatively low (Fig. 4) and no prominent community threshold was detected by the gradient forest analysis for NO3 and TP (Figs. 6 and 7). Common bream and pike-perch are tolerant of eutrophication and their biomass and occurrence seemed to be stimulated either by NO3 or TP. Surprisingly, tench showed a clear preference for lakes with low concentrations of total phosphorus although this species is known to be highly tolerant to hypoxia (Lelek, 1987) which is one of the most dramatic consequences of eutrophication for fish. As a phytophil species (Balon, 1975), it is likely that in eutrophicated lakes where the macrophyte cover is reduced in favor of phytoplankton, tench lacks substrate for its reproduction.

Among the two thresholds related to TP, there is more confidence in the second at $30 \mu \mathrm{g} \cdot \mathrm{L}^{-1}$. This is because the thresholds identified by gradient forest at the extremes of the gradients are often based on very few data and gradient forest does not impose a minimal number of sites on either side of a threshold, unlike other methods (Baker and King, 2010). This second threshold is close to the value of $23.7 \mu \mathrm{g} \cdot \mathrm{L}^{-1}$ reported by Brucet et al. (2013) when fish abundance in European lakes was considered. The two TP thresholds can be compared to the oligotrophic-mesotrophic and mesotrophic-eutrophic boundaries of the OECD diagnostic model, i.e. 10 and $35 \mu \mathrm{g} \cdot \mathrm{L}^{-1}$, respectively (OECD, 1982). They are also similar to other ecological thresholds identified in lakes from the response of zooplankton, phytoplankton or macrophyte communities: 8 and $18 \mu \mathrm{g} \cdot \mathrm{L}^{-1}$ (Soranno et al., 2008), 10, 25 and $70 \mu \mathrm{g} \cdot \mathrm{L}^{-1}$ (Free et al., 2006), 20 and $50 \mu \mathrm{g} \cdot \mathrm{L}^{-1}$ (Penning et al., 2008), and $50 \mu \mathrm{g} \cdot \mathrm{L}^{-1}$ (Roubeix et al., 2016).

Other low importance factors did not provide significant thresholds (Fig. 4, S3). It was the case of dissolved oxygen, although its availability is critical for fish physiology and its depletion is often related to eutrophication. However, it is likely that the sampling protocol was not adapted to account for such effects on fish given the high variability of $\mathrm{O}_{2}$ concentration in space and time in a lake, and the ability of fish to find a refuge in case of severe hypoxia. Moreover, the gradient forest analysis did not well reflect the importance of stressors other than eutrophication or warming, such as acidification or salinization (via $\mathrm{pH}$ or conductivity), probably because they do not represent major causes of lake ecological degradation at the scale of this study.

\section{Conclusion}

The analysis of fish species distribution among French lakes using gradient forest highlighted the importance of geographical and several water physico-chemical parameters, notably temperature, dissolved organic carbon, transparency and, to a lesser extent, nutrients. Important community thresholds can contribute to the definition of environmental standards for lake management. Indeed, if a lake parameter exceeds a threshold, a large change in the composition of a fish assemblage might occur. An environmental standard should account for the whole ecosystem. Therefore, the responses of other group of aquatic organisms with probably different sensitivities to lake physicochemical gradients should be also investigated to complement this study. Moreover, for an appropriate use of ecological thresholds for each site, the natural variability of water parameters among lakes has to be assessed and site-specific reference conditions determined. This study is a first step towards a better understanding of the link between fish and lake water quality from a macroecological point of view. The method of random forest requires a large data set to produce robust results, and the lakes considered in this study were very diverse. When there will be more fishing data on lakes, refined analyses on particular regions or types of lakes will be possible. As an alternative approach to the use of community metrics and linear methods commonly used for WFD implementation, gradient forest can reveal ecologically relevant thresholds that may be useful for lake management.

\section{Supplementary Material}

Supplementary Table S1. Table of Spearman correlation coefficients between environmental parameters.

Supplementary Fig. S2. Results of gradient forest for altitude (alt, log scale). The specific cumulative importance indicates the locations of potential thresholds in the responses of the different fish species to the gradients. The specific response of Squalius cephalus is shown as example. Plain lines are local regressions on strictly positive BPUE values and dashed lines are probabilities of presence along the gradients.

Supplementary Fig. S3. Specific responses of the 20 species taken into account in gradient forest, to the 6 most important physico-chemical parameters. Plain lines are local regressions on strictly positive BPUE values and dashed lines are probabilities of presence along the gradients.

The Supplementary Material is available at http://www.kmaejournal.org/10.1051/kmae/2017032/olm.

Acknowledgments. This research was funded by the French National Agency for Water and Aquatic Environments (Onema). The authors are grateful (1) to the Onema agents who carried out fish sampling, (2) to the French Water Basin Agencies and their partners who contributed to lake data acquisition and (3) to the AFB-Irstea consortium for Lake Hydroecology (Pôle AFBIrstea d'études et de recherche "hydroécologie des plans d'eau", Aix-en-Provence, France), who currently maintains the national biological and physico-chemical database for French lakes. Special thanks to Georges Carrel, Samuel Westrelin, Nathalie Reynaud, Thierry Point and to three anonymous reviewers who contributed to improve this article.

\section{References}

AFNOR. 2015. Qualité de l'eau. La Plaine Saint Denis: AFNOR Editions.

Andersen T, Carstensen J, Hernández-García E, Duarte CM. 2009. Ecological thresholds and regime shifts: approaches to identification. Trends Ecol Evol 24: 49-57.

Argillier C, Pronier O, Irz P. 2002. Approche typologique des peuplements piscicoles lacustres Français. I. Les communautés des plans d'eau d'altitude supérieure à $1500 \mathrm{~m}$. Bull Fr Pêche Piscic 365/366: 373-387. 
Argillier C, Causse S, Gevrey M, et al. 2013. Development of a fishbased index to assess the eutrophication status of European lakes. Hydrobiologia 704: 193-211.

Arranz I, Mehner T, Benejam L, et al. 2016. Density-dependent effects as key drivers of intraspecific size structure of six abundant fish species in lakes across Europe. Can J Fish Aquat Sci 73: 519-534.

Baker ME, King RS. 2010. A new method for detecting and interpreting biodiversity and ecological community thresholds. Methods Ecol Evol 1: 25-37.

Balon EK. 1975. Reproductive guilds of fishes: a proposal and definition. J Fish Res Board Can 32: 821-864.

Birk S, Bonne W, Borja A, et al. 2012. Three hundred ways to assess Europe's surface waters: an almost complete overview of biological methods to implement the Water Framework Directive. Ecol Ind 18: 31-41.

Black RW, Moran PW, Frankforter JD. 2011. Response of algal metrics to nutrients and physical factors and identification of nutrient thresholds in agricultural streams. Environ Monit Assess 175: 397-417.

Blomqvist P, Jansson M, Drakare S, Bergstrom AK, Brydsten L. 2001. Effects of additions of DOC on pelagic biota in a clearwater system: results from a whole lake experiment in northern Sweden. Microb Ecol 42: 383-394.

Breiman L. 2001. Random forests. Mach Learn 45: 5-32.

Brucet S, Pedron S, Mehner T, et al. 2013. Fish diversity in European lakes: geographical factors dominate over anthropogenic pressures. Freshw Biol 58: 1779-1793.

Bruslé J, Quignard J. 2001. Biologie des poissons d'eau douce européens. Paris: Tec\&Doc.

Carlson RE. 1977. Trophic state index for lakes. Limnol Oceanogr 22: 361-369.

CEN. 2005. Water quality - sampling of fish with multi-mesh gillnets. 14757:E.

Chambers PA, Culp JM, Roberts ES, Bowerman M. 2012. Development of environmental thresholds for streams in agricultural watersheds. J Environ Qual 41: 1-6.

Crisp DT. 1996. Environmental requirements of common riverine European salmonid fish species in fresh water with particular reference to physical and chemical aspects. Hydrobiologia 323: 201-221.

Daily JP, Hitt NP, Smith DR, Snyder CD. 2012. Experimental and environmental factors affect spurious detection of ecological thresholds. Ecology 93: 17-23.

Daufresne M, Boet P. 2007. Climate change impacts on structure and diversity of fish communities in rivers. Global Change Biol 13: 2467-2478.

Daufresne M, Roger MC, Capra H, Lamouroux N. 2004. Long-term changes within the invertebrate and fish communities of the Upper Rhone River: effects of climatic factors. Global Change Biol 10: 124-140.

Daufresne M, Lengfellner K, Sommer U. 2009. Global warming benefits the small in aquatic ecosystems. Proc Natl Acad Sci USA 106: $12788-12793$.

Daufresne M, Veslot J, Capra H, et al. 2015. Fish community dynamics (1985-2010) in multiple reaches of a large river subjected to flow restoration and other environmental changes. Freshw Biol 60: 1176-1191.

De'ath G, Fabricius KE. 2000. Classification and regression trees: a powerful yet simple technique for ecological data analysis. Ecology 81: 3178-3192.

Downing JA, Plante C. 1993. Production of fish populations in lakes. Can J Fish Aquat Sci 50: 110-120.

EEB. 2001. Handbook on EU Water Policy under the Water Framework Directive. Brussels: European Environmental Bureau, p. 56.
Ellis N, Smith SJ, Pitcher CR. 2012. Gradient forests: calculating importance gradients on physical predictors. Ecology 93: 156-168.

European Commission. 2000. Directive 2000/60/EC of the European Parliament and of the Council of 23 October 2000 establishing a Framework for Community Action in the Field of Water Policy. The European Parlament and Council, p. 72.

Evans-White MA, Dodds WK, Huggins DG, Baker DS. 2009. Thresholds in macroinvertebrate biodiversity and stoichiometry across water-quality gradients in Central Plains (USA) streams. $J N$ Am Benthol Soc 28: 855-868.

Finstad AG, Helland IP, Ugedal O, Hesthagen T, Hessen DO. 2014. Unimodal response of fish yield to dissolved organic carbon. Ecol Lett 17: 36-43.

FishBase. 2016. World wide web electronic publication. In: Froese R, Pauly D, eds. www.fishbase.org.

Free G, Little R, Tierney D, Donnelly K, Caroni R. 2006. A reference based typology and ecological assessment system for Irish lakes. Prelimnary investigations. Wexford, Ireland: Environmental Protection Agency, p. 266.

Fukami T, Wardle DA. 2005. Long-term ecological dynamics: reciprocal insights from natural and anthropogenic gradients. Proc R Soc B: Biol Sci 272: 2105-2115.

Graham JL, Jones JR, Jones SB, Downing JA, Clevenger TE. 2004. Environmental factors influencing microcystin distribution and concentration in the Midwestern United States. Water Res 38: 4395-4404.

Grenouillet G, Hugueny B, Carrel GA, Olivier JM, Pont D. 2001. Large-scale synchrony and inter-annual variability in roach recruitment in the Rhone River: the relative role of climatic factors and density-dependent processes. Freshw Biol 46: 11-26.

Groffman P, Baron J, Blett T, et al. 2006. Ecological thresholds: the key to successful environmental management or an important concept with no practical application? Ecosystems 9: 1-13.

Holcik J, Banarescu P, Evans D. 1989. General introduction to fishes. In: Holcik J, ed. General introduction to fishes. Acipenseriformes. Wiesbaden: Aula-Verlag, pp. 18-147.

Irz P, Laurent A, Messad S, Pronier O, Argillier C. 2002. Influence of site characteristics on fish community patterns in French reservoirs. Ecol Freshw Fish 11: 123-136.

James A. 1979. The value of biological indicators in relation to other parameters of water quality. In: James A, Evison L, eds. Biological indicators of water quality. Chichester: Wiley, p. 15.

Keith P, Allardi J. 2001. Atlas des poissons d'eau douce de France, 387 p.

Keith P, Persat H, Feunteun E, Allardi J (coords). 2011. Les poissons d'eau douce de France. Mèze, Paris: Biotope, Muséum national d'histoire naturelle (collection Inventaires et biodiversité), $552 \mathrm{p}$.

King RS, Baker ME. 2010. Considerations for analyzing ecological community thresholds in response to anthropogenic environmental gradients. J N Am Benthol Soc 29: 998-1008.

Koenings JP, Edmundson JA. 1991. Secchi disk and photometer estimates of light regimes in Alaskan lakes - effects of yellow color and turbidity. Limnol Oceanogr 36: 91-105.

Lelek A. 1987. Threatened fishes of Europe. Wiesbaden: AULAVerlag $\mathrm{GmbH}, 343 \mathrm{p}$.

Liu JG, Kattel G, Arp HPH, Yang H. 2015. Towards threshold-based management of freshwater ecosystems in the context of climate change. Ecol Model 318: 265-274.

Mac Nally R, Albano C, Fleishman E. 2014. A scrutiny of the evidence for pressure-induced state shifts in estuarine and nearshore ecosystems. Aust Ecol 39: 898-906.

Mann RHK. 1996. Environmental requirements of European nonsalmonid fish in rivers. Hydrobiologia 323: 223-235.

May RM. 1977. Thresholds and breakpoints in ecosystems with a multiplicity of stable states. Nature 269: 471-477. 
MEDDE. 2012. Guide technique: évaluation de l'état des eaux de surface continentales (cours d'eau, canaux, plans d'eau). La Défense: Ministère de l'Ecologie et du Développement Durable et de l'Energie, $84 \mathrm{p}$.

Megard RO, Settles JC, Boyer HA, Combs WS. 1980. Light, Secchi disks, and trophic states. Limnol Oceanogr 25: 373-377.

Mehner T, Diekmann M, Bramick U, Lemcke R. 2005. Composition of fish communities in German lakes as related to lake morphology, trophic state, shore structure and human-use intensity. Freshw Biol 50: $70-85$.

Nunn AD, Cowx IG, Harvey JP. 2002. Recruitment patterns of six species of cyprinid fishes in the lower River Trent, England. Ecol Freshw Fish 11: 74-84

O'Connor MI, Piehler MF, Leech DM, Anton A, Bruno JF. 2009. Warming and resource availability shift food web structure and metabolism. PLoS Biol 7: 1-5.

OECD. 1982. Eutrophication of waters. Monitoring, assessment and control. Cooperative programme on monitoring of inland waters. Paris: Organisation for Economic Co-operation and Development (OECD), p. 154

Ohlberger J, Edeline E, Vøllestad LA, Stenseth NC, Claessen D. 2011. Temperature-driven regime shifts in the dynamics of sizestructured populations. Am Nat 177: 211-223.

Parkinson EA, Lea EV, Nelitz MA, Knudson JM, Moore RD. 2016. Identifying temperature thresholds associated with fish community changes in British Columbia, Canada, to support identification of temperature sensitive streams. River Res Appl 32: 330-347.

Penning WE, Dudley B, Mjelde M, et al. 2008. Using aquatic macrophyte community indices to define the ecological status of European lakes. Aquat Ecol 42: 253-264.

Persson L, Diehl S, Johansson L, Andersson G, Hamrin SF. 1991. Shifts in fish communities along the productivity gradient of temperate lakes - patterns and the importance of size-structured interactions. J Fish Biol 38: 281-293.

Petchey OL, McPhearson PT, Casey TM, Morin PJ. 1999. Environmental warming alters food-web structure and ecosystem function. Nature 402: 69-72.

Pitcher CR, Lawton P, Ellis N, et al. 2012. Exploring the role of environmental variables in shaping patterns of seabed biodiversity composition in regional-scale ecosystems. J Appl Ecol 49: 670-679.

Pourriot R, Meybeck M. 1995. Limnologie générale. Paris: Masson.

R Core Team. 2013. R: a language and environment for statistical computing. Vienna, Austria: R Foundation for Statistical Computing.

Rahel FJ, Nibbelink NP. 1999. Spatial patterns in relations among brown trout (Salmo trutta) distribution, summer air temperature, and stream size in Rocky Mountain streams. Can J Fish Aquat Sci 56: 43-51.

Rall BC, Vucic-Pestic O, Ehnes RB, Emmerson M, Brose U. 2010. Temperature, predator-prey interaction strength and population stability. Global Change Biol 16: 2145-2157.

Reuman DC, Holt RD, Yvon-Durocher G. 2014. A metabolic perspective on competition and body size reductions with warming. J Anim Ecol 83: 59-69.

Reyjol Y, Hugueny B, Pont D, et al. 2007. Patterns in species richness and endemism of European freshwater fish. Global Ecol Biogeogr 16: $65-75$.

Richardson CJ, King RS, Qian SS, Vaithiyanathan P, Qualls RG, Stow CA. 2007. Estimating ecological thresholds for phosphorus in the Everglades. Environ Sci Technol 41: 8084-8091.
Roubeix V, Danis P-A, Feret T, Baudoin J-M. 2016. Identification of ecological thresholds from variations in phytoplankton communities among lakes: contribution to the definition of environmental standards. Environ Monit Assess 188: 246.

Scheffer M, Carpenter SR. 2003. Catastrophic regime shifts in ecosystems: linking theory to observation. Trends Ecol Evolut 18: 648-656.

Smith AJ, Tran CP. 2010. A weight-of-evidence approach to define nutrient criteria protective of aquatic life in large rivers. $J \mathrm{~N} \mathrm{Am}$ Benthol Soc 29: 875-891.

Solheim AL, Rekolainen S, Moe SJ, et al. 2008. Ecological threshold responses in European lakes and their applicability for the Water Framework Directive (WFD) implementation: synthesis of lakes results from the REBECCA project. Aquat Ecol 42: 317-334.

Soranno PA, Cheruvelil KS, Stevenson RJ, et al. 2008. A framework for developing ecosystem-specific nutrient criteria: integrating biological thresholds with predictive modeling. Limnol Oceanogr 53: 773-787.

Souchon Y, Tissot L. 2012. Synthesis of thermal tolerances of the common freshwater fish species in large Western Europe rivers. Knowl Manag Aquat Ecosyst 03: 405.

Strobl C, Boulesteix AL, Kneib T, Augustin T, Zeileis A. 2008. Conditional variable importance for random forests. BMC Bioinform 9: 307.

Sundermann A, Leps M, Leisner S, Haase P. 2015. Taxon-specific physico-chemical change points for stream benthic invertebrates. Ecol Ind 57: 314-323.

Terbraak CJF, Verdonschot PFM. 1995. Canonical correspondenceanalysis and related multivariate methods in aquatic ecology. Aquat Sci 57: 255-289.

Tremblay S, Richard Y. 1993. Effects of acidity on fish communities in southwestern Quebec (Canada). Water Air Soil Pollut 66: 315-331.

Voigt W, Perner J, Davis AJ, et al. 2003. Trophic levels are differentially sensitive to climate. Ecology 84: 2444-2453.

Vollenweider RA. 1975. Input-output models - with special reference to the phoshorus loading concept in limnology. Schweiz Z Hydrol 37: 53-84.

Vucic-Pestic O, Ehnes RB, Rall BC, Brose U. 2011. Warming up the system: higher predator feeding rates but lower energetic efficiencies. Global Change Biol 17: 1301-1310.

Wagenhoff A, Clapcott JE, Lau KEM, Lewis GD, Young RG. 2017. Identifying congruence in stream assemblage thresholds in response to nutrient and sediment gradients for limit setting. Ecol Appl 27: 469-484.

Wehrly KE, Wiley MJ, Seelbach PW. 2003. Classifying regional variation in thermal regime based on stream fish community patterns. Trans Am Fish Soc 132: 18-38.

Williamson CE, Morris DP, Pace ML, Olson AG. 1999. Dissolved organic carbon and nutrients as regulators of lake ecosystems: resurrection of a more integrated paradigm. Limnol Oceanogr 44: 795-803.

Wolter C. 2007. Temperature influence on the fish assemblage structure in a large lowland river, the lower Oder River, Germany. Ecol Freshw Fish 16: 493-503.

Yvon-Durocher G, Jones JI, Trimmer M, Woodward G, Montoya JM. 2010. Warming alters the metabolic balance of ecosystems. Philos Trans R Soc B: Biol Sci 365: 2117-2126.

Cite this article as: Roubeix V, Daufresne M, Argillier C, Dublon J, Maire A, Nicolas D, Raymond J-C, Danis P-A. 2017. Physico-chemical thresholds in the distribution of fish species among French lakes. Knowl. Manag. Aquat. Ecosyst., 418, 41. 